ISSN 0103-5150

Fisioter. Mov., Curitiba, v. 29, n. 1, p. 113-20, Jan./Mar. 2016

Licenciado sob uma Licença Creative Commons

DOI: http://dx.doi.org.10.1590/0103-5150.029.001.A012

\title{
Incorporating environmental factors in gait assessments of persons following amputation
}

\author{
Consideração dos fatores ambientais para avaliar \\ a marcha de indivíduos com amputação
}

\begin{abstract}
Andersom Ricardo Fréz, Christiane Riedi Daniel, Ivo Ilvan Kerppers, João Afonso Ruaro, Jussara Paula da Luz, Marinez Boeing Ruaro*
\end{abstract}

Universidade Estadual do Centro-Oeste (UNICENTRO), Guarapuava, PR, Brazil

\begin{abstract}
Introduction: Environmental factors have also been recognized to be a component of a multidimensional gait assessment of people living with disabilities, like persons following an amputation. Objective: To investigated whether the environmental factors outlined by the International Classification of Functioning, Disability, and Health (ICF) are considered when evaluating gait following lower limb amputations. Materials and methods: A literature search of the PubMed, EMBASE, CINAHL, and SPORTDiscus databases was performed. The keywords "amputation" and "gait" were combined with the keywords "barriers", "facilitators", and "environmental factors". Searches were performed without language restrictions. All articles containing data about environmental influences on gait functionality after lower limb amputations published during or after 2002, were included. Manuscripts that did not study adults and literature reviews were excluded.
\end{abstract}

\footnotetext{
* ARF: MSc, e-mail: andersom_frez@yahoo.com.br CRD: MSc, e-mail: christiane_riedi@hotmail.com IIK: PhD, e-mail: ikerppers@hotmail.com JAR: PhD, e-mail: joaoruaro@gmail.com JPL: grad, e-mail: jufisioo@gmail.com MBR: specialist, e-mail: marinezx@bol.com.br
} 
Two researchers identified potentially eligible articles and the methods used to assess gait. To make comparisons between scales, the 2 researchers selected the categories from the ICF chapter on environmental factors. Results: Fourteen studies were obtained from the search. Seven studies were duplicates and 4 were excluded. The remaining 3 articles were evaluated. We identified a total of 74 possibilities for categorization according to the ICF environmental factors, but only 7 ICF categories $(9.45 \%)$ were considered in the studies analyzed. Conclusions: The influence of environmental factors is frequently not considered in the evaluation of gait following a lower limb amputation. Thorough evaluation of gait after lower limb amputation should reflect the complex nature of gait changes, including environmental factors.

Keywords: Amputation. Gait. International Classification of Functioning. Disability and Health.

\section{Resumo}

Introdução: Fatores ambientais fazem parte da avaliação multidimensional da marcha de pessoas que vivem com deficiência, como as que possuem uma amputação. Objetivo: Investigar se os fatores ambientais definidos pela Classificação Internacional de Funcionalidade, Incapacidade e Saúde (CIF) são considerados quando se avalia a marcha de indivíduos com amputação de membros inferiores. Materiais e métodos: Foi realizada uma revisão consultando as bases de dados PubMed, EMBASE, CINAHL, e SPORTDiscus. Utilizaram-se os termos "amputação" e "marcha" combinados com os termos "facilitadores", "barreiras" e "fatores ambientais". As pesquisas foram realizadas sem restrições de idioma. Foram incluídos os artigos publicados no ano de 2002 e a partir dele, que continham dados sobre a influência dos fatores ambientais sobre a funcionalidade da marcha em indivíduos com amputação de membros inferiores. Dois pesquisadores identificaram, selecionaram os artigos, identificaram os métodos e instrumentos usados para avaliar a marcha. Para comparar as escalas dois pesquisadores selecionaram as categorias dos capítulos fatores ambientais da CIF. Resultados: Foram identificados 14 estudos, destes sete eram duplicatas e quatro não tinham relação com os objetivos estudados. Dos três artigos restantes foram identificadas 74 possibilidades de categorização com os fatores ambientais das CIF, porém apenas 7 categorias (9,45\%) puderam ser correlacionadas. Conclusões: Os fatores ambientais não são comumente considerados na avaliação da marcha de indivíduos com amputação de membros inferiores. Uma avaliação após uma amputação de membros inferiores reflete a complexidade das alterações da marcha, as quais incluem os fatores ambientais.

Palavras-chave: Amputação. Marcha. Classificação Internacional de Funcionalidade. Incapacidade e Saúde.

\section{Introduction}

Amputation has serious aesthetic, functional, emotional, social, economic, and psychological consequences (1). Several complications can negatively affect rehabilitation for amputees such as stump pain, flexion deformity, painful neuromas, skin complications, vascular damage, bones irregularities, excess soft tissue (2), sensation and phantom pain (3).

Basic activities of daily living, work, and rest present unique challenges that can negatively impact selfesteem of amputees (4). For persons following amputations of the lower extremities, the main limitation is difficulty walking, which limits function necessary for independent living (5). Reduced motor abilities can have additional negative effects on the mental health of these individuals (6).
No systematic evaluation to assess function of amputees currently exists because there is no consensus on which scales or instruments should be used (5, $7,8)$. The use of assessment tools that have not yet been validated or are not standard makes it impossible to compare results and reduces the reliability and reproducibility of studies (9). The International Classification of Functioning, Disability, and Health (ICF) seeks to establish common measurements and language for health and disability outcome measurements. Since 2001, the ICF has advocated for assessment of human functioning and disability to consider factors such as the environment and personal characteristics that affect quality of life. Accordingly, the ICF provides a standard classification that accounts for the presence and severity of health problems and their impact on the individual and society (10). 
The ICF uses an alphanumeric coding system where letters refer to a particular component (e.g., body functions (b), body structures (s), activities and participation (d), and environmental factors (e)) and numbers refer to the chapter (or first level categories) and categories of the second, third, or fourth level. The detail of categories is progressive where the first level is the most general and fourth level is the most detailed. To provide additional meaning to ICF codes, a numerical qualifier from 0 to 4 is assigned to indicate the severity of the problem. Zero indicates no problem and 4 indicates the most severe problem. The numbers 8 and 9 are also used as qualifiers and mean "unspecified" and "not applicable", respectively (10).

Environmental factors have also been recognized by the ICF to be a component of a multidimensional assessment of people living with disabilities (11, 12), like amputees, who reported perceiving substantial problems in the environment $(13,14)$. These factors are important because they influence the rehabilitation process for these patients (15). According to the ICF, environmental factors are defined as the physical, social, and attitudinal environment in which people live and conduct their lives. These factors are external to individuals and can positively (facilitator) or negatively (barrier) influence several aspects of a person's life. These aspects include performance of the individual in society, the capabilities of the individual to execute actions or tasks, and the function or structure of the person's body. The ICF divides environmental factors into 5 chapters: 1) products and technology, 2) natural environment and human-made changes to the environment, 3) support and relationships, 4) attitudes, and 5) services, systems, and policies (10). It is essential to investigate whether environmental factors outlined by the ICF are considered during evaluations of gait in persons following a lower limb amputation.

\section{Materials and Methods}

This study was an integrative literature review that is a wide methodological approach that can include diverse study designs and allows review of theories and evidence to provide a complete understanding of the phenomenon analyzed (16).
Data sources and searches

Studies were searched for using the PubMed, EMBASE, CINAHL, and SPORTDiscus databases. Using Boolean operators the keywords "amputation" AND "gait" were combined with "environmental factors" OR "barriers" OR "facilitators". The search did not have language restrictions and was conducted in May 2013 in all indexes field.

\section{Selection criteria}

All articles that investigated the influence of environmental factors on gait in persons following a lower limb amputation were collected. The ICF was released in 2001, and therefore, only articles published during or after 2002 and published until May 2013 were included. Studies of children (under 18 years of age), literature reviews, thesis and letters to the editor were excluded.

\section{Selection of articles}

Duplicate search results (articles retrieved by 2 or more databases) were removed. Titles and abstracts of the remaining articles were screened by 2 researchers to identify potentially eligible articles. Researchers met to discuss studies that would be included or excluded. The study designated a third researcher to resolve any disputes over inclusion/ exclusion of articles, but no disputes occurred.

\section{Environmental factors selection}

To reliably correlate the assessment tools used in studies with the ICF environmental factors, the eight standards sequence proposed by Cieza et al. (17) was used. The 8 standards are: 1) Before one links meaningful concepts to the ICF categories, they should understand the conceptual and taxonomical fundaments of the ICF, as well as the chapters, domains, and categories of the detailed classification, including definitions; 2) Each meaningful concept is linked to the most precise ICF category; 3) Do not use the so-called "other specified" ICF category uniquely identified by the final code " 8 ". If the content of a meaningful concept is not explicitly named in the 
corresponding ICF category, the additional information not explicitly named in the ICF is documented; 4) Do not use the so-called "unspecified" ICF category uniquely identified by the final code " 9 ", but the lower level category instead; 5) If the information provided by the meaningful concept is insufficient to determine the most precise ICF category it should be linked to, the meaningful concept is assigned "nd" (not definable); 6) If the meaningful concept is not contained in the ICF, but it is clearly a personal factor defined by the ICF, the meaningful concept will be assigned "pf" (personal factor); 7) If the meaningful concept is not contained in the ICF and it is clearly not a personal factor, this meaningful concept is assigned "nc" (not covered by ICF); 8) If the meaningful concept refers to a diagnosis or a health condition, the meaningful concept will be assigned "hc" (health condition).

In order to establish the relationship between scales, 2 researchers with different healthcare backgrounds, but both working in rehabilitation, independently selected categories of the ICF environmental factors chapter that could be related to the criteria evaluated by the studies. For this, each measure evaluated was compared with a detailed description of each category in the ICF. Once the relationship was established, the 2 researchers agreed on the inclusion or exclusion of each category. Had agreements not been reached regarding any category, a third researcher would have resolved disputes, but this was not necessary.

\section{Results}

A total of 14 studies were obtained from our database searches. Seven of these studies were excluded because they were duplicates and 4 were excluded because they investigated topics unrelated to the aims of this study (barriers to assess educational programs, neurotoxicity by prolonged use of metronidazole, balance deficits during cardiac rehabilitation, and a literature review of postoperative complications). The remaining 3 studies were evaluated and methods used to assess gait following lower limb amputation were identified (Figure 1). Environmental factors identified in measurements are outlined in Table 1. In the analyzed studies, there were a total of 74 possible categorizations of environmental factors defined by the ICF, but only 7 (9.45\%) ICF categories were used.

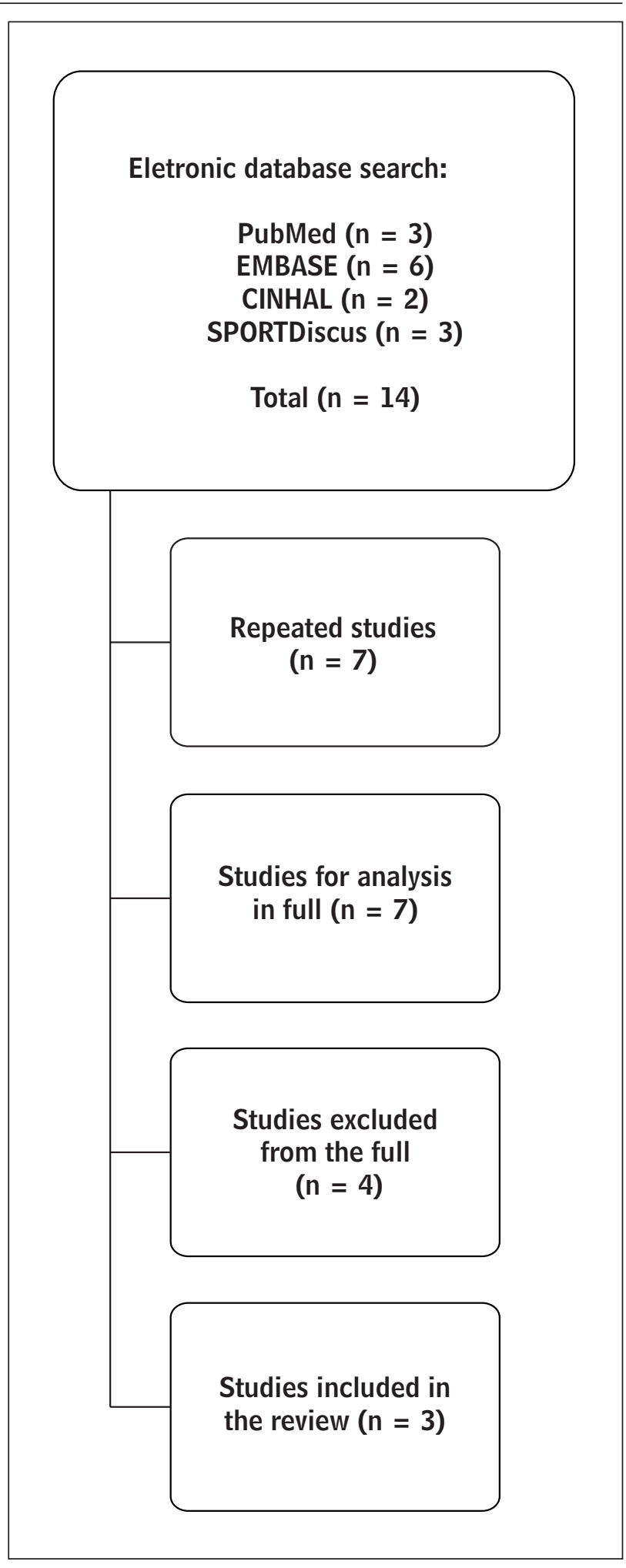

Figure 1 - Flow chart of the selection of the studies

\section{Discussion}

This study identified and analyzed the environmental factors that are considered during gait 
evaluation in persons following lower limb amputation. This study focused on environmental factors because the ICF views disabilities not only as dysfunctions of the person, but also the impacts they have on social activities. Additionally, the ICF recognizes the importance of environmental factors that influence functional independence, either by facilitating it or obstructing it (10).

Table 1 - Assessments of environmental factors that can be correlated to the ICF classification

\begin{tabular}{|c|c|c|c|}
\hline Study & Assessment tools & Environmental factors assessed & $\begin{array}{l}\text { Corresponding ICF envi- } \\
\text { ronmental factors }\end{array}$ \\
\hline Dudek et al., 2008 & $\begin{array}{l}\text { Patient Activity Monitor } \\
\text { Digi-Walker pedometer }\end{array}$ & Home environment & e155 \\
\hline \multirow[t]{7}{*}{$\begin{array}{l}\text { Hafner and Smith, } \\
2009\end{array}$} & Amputee Mobility Predictor & $\begin{array}{l}\text { Walking, up and down stairs, and } \\
\text { assistive devices for walking }\end{array}$ & e115, e150, e155 \\
\hline & $\begin{array}{l}\text { Prosthesis Evaluation } \\
\text { Questionnaire }\end{array}$ & $\begin{array}{l}\text { Prosthetic use in close spaces, stairs, } \\
\text { hills, sidewalks, streets, slippery } \\
\text { surfaces; } \\
\text { Perceptions of strangers, friends, } \\
\text { partners, and family members' } \\
\text { reactions }\end{array}$ & $\begin{array}{c}\text { e115, e150, e155, e355, e410, } \\
\text { e420, e445 }\end{array}$ \\
\hline & $\begin{array}{l}\text { 36-Item Short Form Healthy } \\
\text { Survey }\end{array}$ & None & - \\
\hline & Hill Assessment Index & Hill walking & e150, e155 \\
\hline & Stair Assessment Index & Stair walking & e150, e155 \\
\hline & Obstacle course & Uneven terrain & e150, e155 \\
\hline & Attention demands & None & - \\
\hline Gates et al., 2012 & $\begin{array}{l}\text { Three-dimensional kinematic } \\
\text { gait evaluation }\end{array}$ & Destabilizing rock surface & e150, e155 \\
\hline
\end{tabular}

Our search returned 3 eligible studies. The first compared the accuracy of 2 methods to assess step count and ambulation distance (18). The second study evaluated differences in function and safety in persons with transfemoral amputations that were using passive mechanically-controlled prosthetics or active microprocessor-controlled prosthetics over extend periods of time (19). The third study quantified gate adaptations in transtibial amputees when walking on a destabilized rock surface (20). We found that few assessments in these studies considered the environmental factors defined by the ICF.

One of the assessments used in the 3 studies was the Amputee Mobility Predictor (AMP). The AMP was designed as a clinical tool to assess an amputee's mobility and for assessing existing and potential functional ambulation for lower limb amputees. It can be used before and after fitting of prosthetic limbs. It consists of 21 items, spread across 6 domains: sitting balance, transfer, standing balance, walking, moving up and down stairs, and the use of devices to assist walking (21). The first 18 items of the AMP consider activities and participation described by the ICF, because they assess body positions, transfers, daily activities, and gait. Items 19 and 20 consider walking with obstacles and stairs, which pertain to the ICF categories e150 (design, construction and building products, and technology of buildings for public use) and e155 (design, construction and building products, and technology of buildings for private use). Item 21 considers the use of devices to assist walking, which pertains to the ICF category e115 (products and technology for personal use in daily living).

The Prosthesis Evaluation Questionnaire (PEQ) is a specific tool to assess quality of life and is composed of multiple questions in 7 groups: the prosthesis, bodily sensations, the social and emotional aspects of using a prosthesis, mobility, satisfaction with particular situations, daily activities, and importance of the prosthesis (22). All questions pertain to the ICF category e115 (products and technology for personal use in daily living). The questions about social and 
emotional aspects pertain to categories e410 (individual attitudes of immediate family members), e420 (individual attitudes of friends), and e445 (individual attitudes of strangers). The questions regarding mobility pertain to the ICF categories e150 (design, construction and building products, and technology of buildings for public use) and e155 (design, construction and building products, and technology of buildings for private use). The satisfaction with particular situations pertains to e355 (health professionals).

The 36-Item Short Form Healthy Survey (SF-36) consists of 8 scales that collectively assess physical and mental health. The measures of physical health are physical functioning, physical role functioning, bodily pain, and general health perceptions. The mental health scales assess vitality, social functioning, emotional role functioning, and general mental health. Although the SF-36 considers quality of life with respect to health, it does not include any of the environmental factors considered by the ICF, and therefore it does not make comprehensive assessments of function in the manner advocated by the ICF. This fact has been demonstrated by a study that correlated the SF-36 to the ICF (23).

The Hill Assessment Index (HAI) rates function on inclines and measures walking speed and step length on a 190, 94-foot-long paved sidewalk. The Stair Assessment Index (SAI) assesses function on stairs. Both tests assess gait quality by observing the subject's use of a handrail (or other assistive device) and foot placement. It also evaluates subjects walking down inclined surfaces and down stairs (24). The HAI can be correlated with the ICF categories e150 (design, construction and building products, and technology of buildings for public use) or e155 (design, construction and building products, and technology of buildings for private use). The SAI can be related with the same HAI categories.

A three-dimensional kinematic gait evaluation (20) was also performed. Measurements of step count and ambulation distance were also made with Patient Activity Monitors (PAM) and Yamax Digi-Walker pedometers (18). For this evaluation, subjects walked across level ground and over a destabilized rock surface at 4 controlled speeds and were imaged by a 20-camera infrared motion capture system (20). We correlated the destabilizing rock surface with the ICF categories e150 (design, construction and building products, and technology of buildings for public use) and e155 (design, construction and building products, and technology of buildings for private use). To compare the accuracy of the PAM and the pedometer, the walking test simulated outdoor walking on even terrain without environmental barriers. Subjects also simulate household activities. They started from a seated position in a bed, stood up, and walked to a bathroom sink. The subject then walked from the bathroom into a kitchen, then into a dining room, and returned to the kitchen. In each room, subjects simulated daily activities (18). The environmental factors were the home environment and furniture which correspond to the ICF category e155 (design, construction and building products, and technology of buildings for private use).

The ability to negotiate uneven terrain was evaluated by measuring walking speed on a 244-foot outdoor obstacle course that included grass, wood chips, sand, a cement ramp, and cement stairs. In addition ambulation with an attentional demand was measured by mean speed and accuracy on a verbal reverse-numbers test as subjects walked 2 sides of a busy city block while simultaneously responding to test questions (19).

In situations like navigating stairs $(21,22,24)$, uneven terrain $(19,20,22)$ and furniture and the home environment $(18,22)$, it was possible to use the thirdlevel ICF classifications e1508 (design, construction and building products, and technology of buildings for public use, other specified) or e1558 (design, construction and building products, and technology of buildings for private use, other specified) to account for environmental factors. Neither of these categories were used because the third standard in the sequence proposed by Cieza et al. (17) recommended against the use of the "other specified" ICF category identified by a terminal " 8 " in the code.

In this study, we identified 7 (9.45\%) of the 74 twolevel ICF categories that were measured in included studies. The highest frequency of the ICF environmental factors that could be associated with the methods to assess gait following a lower limb amputation fall under the chapter 1 classification (products and technology). The higher frequency of measurements from chapter 1 could be due to the emphasis on products and technologies in rehabilitation, since most of these measurements were developed to assess rehabilitation. Similar results were also reported by Reinhardt et al. (25) and Alvarelhão et al. (11). Advanced technology benefits less mobile subjects, enabling them to achieve higher levels of activity. 
Factors outlined in chapters 2 (natural environment and human-made changes to environment) and 5 (services, systems and policies) were not considered in the included studies. This is alarming and raises attention to the fact that assessment of amputees should be multidisciplinary and comprehensive and these studies fail to consider pertinent environmental factors, aside from products and technology, which can influence the quality of life for patients.

There was heterogeneity in the assessments. Assessments did not use uniform methodologies and they employed a combination of questionnaires, anthropometric measurements, functional tests, and kinetic and kinematic ratings. The heterogeneity between methodologies could reflect the complexity of evaluating environmental factors. The reason that specific tests do not assess ICF environmental factors could be due to the relative novelty of ICF classifications, a fact noted in previous research $(26$, 27). However, to enhance the feasibility of its use, the core sets project began to be developed, and its goal being to establish a tailored selection of categories to represent the standards of specific groups for multidisciplinary approach (28), and a core set for people with amputations is being developed $(29,30)$.

A limitation of this study may be the search terms. They are comprehensive and may not specifically identify all studies integrating ICF environmental factors. It is also possible that other studies assessing gait amputees did consider environmental factors, but do not use the keywords our study searched for, and thus were not discovered.

\section{Conclusions}

According to our search, evaluation of amputees frequently fails to consider the influence of environmental factors in gait assessment after lower limb amputation should consider them to fully understand the complex changes in gait following amputation.

\section{References}

1. Lima KBB, Chamlian TR, Masiero D. Phantom pain in lower limb amputees as a predictive factor for the acquisition of gait with prosthesis use. Acta Fisiatr. 2006;13(3):157-62.
2. Pastre CM, Salioni JF, Oliveira BAF, Micheletto M, Júnior JN. Physical therapy and transtibial amputation. Arq Ciênc Saúde. 2005;12(2):120-4.

3. Probstner D, Thuler LCS. Prevalence of phantom pain in amputee: a systematic literatue review. Rev Bras Cancerol. 2006;52(4):395-400.

4. Bruins M, Geertzen JH, Groothoff JW, Schoppen T. Vocational reintegration after a lower limb amputation: a qualitative study. Prosthet Orthot Int. 2003;27(1):4-10.

5. Kageyama ERO, Yogi M, Sera CTN, Yogi LS, Pedrinelli A, Camargo OP. Brazilian-Portuguese validation of Functional Measure for Amputees Questionnaire. Fisioter Pesq. 2008;15(2):164-71.

6. Abdalla AA, Galindo J, Ribeiro SC, Riedi C, Ruaro JA, Fréz AR. Correlation between quality of life and locomotor capabilities of persons following a lower limb amputation. Conscientiae Saúde. 2013;12(1):106-13.

7. Vidal ALA, Santos CC, Nishimaru S, Chamlian TR, Masiero D. Avaliação da qualidade de vida em pacientes amputados de membros inferiores. Med Reabil. 2004;23(1):12-7.

8. Hawkins AT, Henry AJ, Crandell DM, Nguyen LL. A systematic review of functional and quality of life assessment after major lower extremity amputation. Ann Vasc Surg. 2014;28(3):763-80.

9. Chamlian TR, Melo ACO. Functional assessment after lower limb amputation. Acta Fisiatr. 2008;15(1):49-58.

10. World Health Organization (WHO). International Classification of Functioning, Disability and Health: ICF. Geneva: WHO; 2001.

11. Alvarelhão J, Silva A, Martins A, Queirós A, Amaro A, Rocha N, Lains J. Comparing the content of instruments assessing environmental factors using the International Classification of Functioning, Disability and Health. J Rehabil Med. 2012;44:1-6.

12. Schneidert M, Hurst R, Miller J, Ustün B. The role of environment in the International Classification of Functioning, Disability and Health (ICF). Disabil Rehabil. 2003;25(11-12):588-95. 
13. Ephraim PL, MacKenzie EJ, Wegener ST, Dillingham TR, Pezzin LE. Environmental barriers experienced by amputees: the Craig hospital inventory of environmental factors-short form. Arch Phys Med Rehabil. 2006;87(3):328-33.

14. Gallagher P, O'Donovan MA, Doyle A, Desmond D. Environmental barriers, activity limitations and participation restrictions experienced by people with major limb amputation. Prosthet Orthot Int. 2011;35(3):278-84.

15. Stucki G, Cieza A, Melvin J. The International Classification of Functioning, Disability and Health: a unifying model for the conceptual description of the rehabilitation strategy. J Rehabil Med. 2007;39:279-85.

16. Whittemore R, Knafl K. The integrative review: update methodology. J Adv Nurs. 2005;52(5):546-53.

17. Cieza A, Geyh S, Chatterji S, Kostanjsek N, Üstün B, Stucki G. ICF linking rules: an update based on lessons learned. J Rehabil Med. 2005;37:212-8.

18. Dudek NL, Khan OD, Lemaire ED, Marks MB, Saville L. Ambulation monitoring of transtibial amputation subjects with patient activity monitor versus pedometer. JRRD. 2008;45(4):577-86

19. Hafner BJ, Smith DG. Differences in function and safety between Medicare Functional Classification Level-2 and -3 transfemoral amputees and influence of prosthetic knee joint control. J Rehabil Res Dev. 2009;46(3):417-33.

20. Gates DH, Dingwell JB, Scott SJ, Sinitski EH, Wilken JM. Gait characteristics of individuals with transtibial amputations walking on a destabilizing rock surface. Gait Posture. 2012;36(1):33-9.

21. Gailey RS, Roach KE, Applegate EB, Cho B, Cunniffe B, Licht S, Maguire M, Nash MS. The amputee mobility predictor: an instrument to assess determinants of the lower-limb amputee's ability to ambulate. Arch Phys Med Rehabil. 2002;83(5):613-27.

22. Legro MW, Reiber GD, Smith DG, del Aguila M, Larsen J, Boone D. Prosthesis evaluation questionnaire for persons with lower limb amputations: assessing prosthesis-related quality of life. Arch Phys Med Rehabil. 1998;79(8):931-8.
23. Fréz AR, Abdallah AA, Riedi C, Galindo J, Ruaro JA, Ribeiro SC. Proposta de utilização da classificação internacional de funcionalidade, incapacidade e saúde na avaliação da qualidade de vida de pessoas com amputação. Fisioter Mov. 2014;27(1):49-56.

24. Hafner BJ, Willingham LL, Buell NC, Allyn KJ, Smith DG. Evaluation of function, performance, and preference as transfemoral amputees transition from mechanical to microprocessor control of the prosthetic knee. Arch Phys Med Rehabil. 2007;88(2):207-17.

25. Reinhardt JD, Miller J, Stucki G, Sykes CR, Gray D. Measuring impact of environmental factors on human functioning and disability: a review of various scientific approaches. Disabil Rehabil. 2011;33:23-4.

26. Ruaro JA, Ruaro MB, Souza DE, Fréz AR, Guerra RO. An overview and profile of the ICF's use in Brazil: a decade of history. Rev Bras Fisioter. 2012;16(6):454-62.

27. Comín Comín M, Ruiz Garrós C, Franco E, Damian J, Ruiz Tovar M, de Pedro-Cuesta J. Scientific-professional production on the ICF disability model in Spain. A literature review (2001-2010). Gac Sanit. 2011;25(2):39-46.

28. Røe C, Sveen U, Geyh S, Cieza A, Bautz-Holter E. Construct dimensionality and properties of the categories in the ICF Core Set for low back pain. J Rehabil Med. 2009;41(6):429-37.

29. Kohler F, Cieza A, Stucki G, Geertzen J, Burger H, Dillon MP, Schippacasse C, Esquenazi A, Kistenberg RS, Kostanjsek N. Developing core sets for persons following amputation based on the International Classification of Functioning, Disability and Health as a way to specify functioning. Prosthet Orthot Int. 2009;33(2):117-29.

30. Kohler F, Xu J, Silva-Withmory C, Arockiam J. Feasibility of using a checklist based on the International Classification of Functioning, Disability and Health as an outcome measure in individuals following lower limb amputation. Prosthet Orthot Int. 2011;35(3):294-301.

Recebido: 08/05/2014

Received: 05/08/2014

Aprovado: 06/07/2015

Approved: 07/06/2015 